\title{
PERFORMANCE AND EGG QUALITY OF HENS FROM CONSERVATION FLOCKS FED A DIET CONTAINING MAIZE DISTILLERS DRIED GRAINS WITH SOLUBLES (DDGS)*
}

\author{
Józefa Krawczyk ${ }^{1}$, Zofia Sokołowicz², Sylwester Świątkiewicz², \\ Jerzy Koreleski³, Maja Szefer ${ }^{1}$ \\ ${ }^{1}$ Department of Animal Genetic Resources Conservation, National Research Institute of Animal \\ Production, 32-083 Balice n. Kraków, Poland \\ ${ }^{2}$ Department of Animal Production and Poultry Products Evaluation, University of Rzeszów, \\ Ćwiklińskiej 2, 35-601 Rzeszów, Poland \\ ${ }^{3}$ Department of Animal Nutrition and Feed Science, National Research Institute of Animal Production, \\ 32-083 Balice n. Kraków, Poland \\ Corresponding author: jkrawczy@izoo.krakow.pl
}

\begin{abstract}
The objective of the study was to evaluate laying performance and quality indices of consumption and hatching eggs in hens from conservation flocks fed a diet containing maize distillers dried grains with solubles (DDGS). A total of 360 Greenleg Partridge (Z-11) and Rhode Island Red (R-11) hens, included in the genetic resources conservation programme in Poland, were investigated. The good performance obtained by layers fed the DDGS diet indicates that maize distillers dried grains with solubles can serve as a useful source of protein in the nutrition of hens from conservation flocks, partly replacing imported soybean meal. The dietary inclusion of DDGS improved laying performance while maintaining hatchability traits and the quality of consumption eggs. The DDGS diet had an effect on nutritionally important egg quality traits, i.e. increased protein content of egg albumen and increased concentration of oleic and linoleic acids in yolk lipids, with a simultaneous increase in $n-6: n-3$ PUFA ratio. Dietary inclusion of DDGS also increased yolk colour intensity and Haugh units while having no effect on eggshell quality.
\end{abstract}

Key words: laying hens, conservation flocks, hatchability, maize DDGS, egg quality

In line with sustainable agricultural development strategy, European Union directives require member countries to produce fuels containing biocomponents. The Polish act, which sets out the conditions under which natural petrol and diesel additives can be produced, also creates favourable conditions for development of this

"Supported by grant no. N R12 008310 financed by the National Centre for Research and Development. 
branch of industry. Because of its potential for high yields, relatively low soil requirements and high grain starch content, maize will likely become the principal plant used in bioethanol production. A co-product of bioethanol manufacture, distillers dried grains with solubles (DDGS) are produced during alcohol fermentation. The most effective and environmentally friendly way of using DDGS is to feed farm animals, including poultry (Świątkiewicz and Koreleski, 2008).

Results of some studies have shown that DDGS are a source of valuable protein and no synthetic sulphur amino acids need to be supplemented to layer diets containing up to 10\% DDGS (Matterson et al., 1966; Harms et al., 1969). Some authors reported that DDGS also contain components, mainly trace elements ( $\mathrm{Fe}, \mathrm{Cu}, \mathrm{Zn}$, Se and $\mathrm{Cr}$ ), that improve protein quality, as reflected in increased Haugh units (Damron et al., 1976; Jensen et al., 1978; Jensen and Maurice, 1980). Allen et al. (1979) showed that dietary inclusion of DDGS at $15 \%$ did not reduce performance indices in brown egg laying hens, however in Leghorn white egg layers such a dietary level of DDGS decreased laying performance. In addition, Leaflet et al. (2006) reported that dietary inclusion of $10 \%$ maize DDGS to laying hens reduces ammonia emissions from manure by approximately $50 \%$, which is of crucial importance for environmental protection. Addition of DDGS to laying hen diets was also shown to have a beneficial effect on nitrogen and phosphorus balance by increasing retention and decreasing fecal excretion of these elements (Świątkiewicz and Koreleski, 2007 a; Masa'deh et al., 2011).

The objective of the study was to evaluate the laying performance and quality of consumption and hatching eggs in hens from two conservation flocks fed a diet containing maize distillers dried grains with solubles.

\section{Material and methods}

\section{Animals and experimental diets}

The experiment was carried out with Greenleg Partridge (Z-11) and Rhode Island Red (R-11) hens, participating in the genetic resources conservation programme in Poland, at the Experimental Station of the National Research Institute of Animal Production in Chorzelów. Birds of each breed/line were assigned to 2 groups of 180 hens per group (male to female ratio 1:10). Each group had 4 replications. The control group (C) received a complete standard diet and the experimental group (E) was fed a diet containing 10.4\% DDGS. The experiment was conducted from 20 to 56 weeks of age. The complete diets were formulated in accordance with nutrient recommendations (Smulikowska and Rutkowski, 2005). Layers were maintained on litter under controlled climate conditions (temperature $16-18^{\circ} \mathrm{C}$, relative humidity $70 \%$, light schedule 16L: 8D) and fed ad libitum with constant access to water. Performance results were determined based on mortality levels (\%), hen-housed egg number, laying percentage, feed intake per hen, feed consumption per egg laid, and egg weight. Hatching eggs were evaluated based on percent egg fertility, percent hatchability from set eggs, and percent hatchability from fertilized eggs. 


\section{Chemical analyses and sensory evaluation of eggs}

The chemical composition of the complete diets was determined using standard procedures (AOAC, 1997), and the results are given in Table 1. At 56 weeks of age, 50 eggs were randomly collected from each group, 20 of which were analysed for physical characteristics using the EQM (Egg Quality Management) system. Shell strength $[\mathrm{N}]$ was determined with an Egg Crusher. The other eggs were subjected to chemical analysis at the Central Laboratory of the National Research Institute of Animal Production. Fatty acid profile, levels of vitamins A and E, and cholesterol content were determined in the yolk of eggs. Egg albumen was analysed for protein content and for the content and hydrolytic activity of lysozyme in thick and thin albumen in accordance with the method of Kijowski and Leśnierowski (1999). Cholesterol levels were determined in 6 yolks from each group by gas chromatography (Rong-Zhen et al., 1999). The fatty acid profile of the diets and yolks was determined on a VARIAN $3400 \mathrm{CX}$ gas chromatograph, using helium as a carrier gas, and a $105 \mathrm{~m} \mathrm{Rtx} 2330$ column. Injector temperature was $200^{\circ} \mathrm{C}$ and detector temperature was $240^{\circ} \mathrm{C}$. Samples were prepared according to Folch et al. (1957) using methylation with BF3/methanol. The total protein content of egg albumen was determined according to Kjeldahl, and vitamin A and E levels using high-performance liquid chromatography (HPLC) according to SOP M.003a procedure. Cooked eggs were subjected to sensory evaluation by a panel of 14 evaluators. Yolk colour, aroma and flavour were evaluated on a scale of 1 to 5 , with 5 representing maximum score.

Hatchability parameters were determined based on 5200 randomly chosen hatching eggs, which were laid by the hens from 47 to 52 weeks of age. Eggs were incubated in PETERSIME incubators with automatic control of temperature and relative humidity, adjusted to hens' eggs. Unfertilized eggs and eggs with dead embryos were identified by candling at 6 and 18 days of incubation.

Table 1. Ingredient composition and results of chemical analysis of the hen diets

\begin{tabular}{|c|c|c|}
\hline Item & Control & DDGS \\
\hline 1 & 2 & 3 \\
\hline \multicolumn{3}{|c|}{ Ingredient composition (\%) } \\
\hline Wheat & 36.13 & 28.76 \\
\hline Maize & 29.00 & 29.0 \\
\hline Soybean meal & 16.32 & 13.30 \\
\hline DDGS & 0.0 & 10.40 \\
\hline Ground limestone & 8.90 & 8.90 \\
\hline Rapeseed oil & 1.50 & 1.50 \\
\hline Rapeseed expeller cake & 3.0 & 3.0 \\
\hline Dried forage & 3.0 & 3.0 \\
\hline Calcium hydrogen phosphate & 1.40 & 1.40 \\
\hline $\mathrm{NaCl}$ & 0.3 & 0,3 \\
\hline DL-Met (99\%) & 0.09 & 0.09 \\
\hline L-Lys (65\%) & 0.18 & 0.18 \\
\hline Vitamin-mineral premix $^{1}$ & 0.18 & 0.18 \\
\hline
\end{tabular}


Table 1 - contd.

\begin{tabular}{|c|c|c|}
\hline 1 & 2 & 3 \\
\hline \multicolumn{3}{|c|}{ Chemical composition (\%) } \\
\hline Metabolizable energy (MJ/kg) & 11.3 & 11.3 \\
\hline Protein & 16.0 & 16.1 \\
\hline Crude fibre & 3.12 & 3.46 \\
\hline Met + Cys & 0.65 & 0.67 \\
\hline Lys & 0.84 & 0.80 \\
\hline $\mathrm{Ca}$ & 3.76 & 3.76 \\
\hline Total P & 0.63 & 0.66 \\
\hline \multicolumn{3}{|c|}{ Fatty acids (g/100 g) } \\
\hline $\mathrm{C} 16$ & 9.82 & 9.84 \\
\hline $\mathrm{C} 16: 1$ & 0.17 & 0.16 \\
\hline C18:1 & 38.44 & 36.08 \\
\hline $\mathrm{C} 18: 2$ & 38.50 & 42.26 \\
\hline $\mathrm{C} 18: 3, n-3$ & 6.96 & 5.72 \\
\hline EPA & 0.13 & 0.25 \\
\hline SFA & 12.39 & 12.41 \\
\hline UFA & 87.62 & 87.59 \\
\hline MUFA & 39.77 & 37.34 \\
\hline PUFA-6 & 38.56 & 42.29 \\
\hline PUFA-3 & 7.09 & 5.97 \\
\hline PUFA 6/3 & 5.44 & 7.09 \\
\hline
\end{tabular}

${ }^{1}$ The premix provided, per kg of diet: vitamin $\mathrm{A}, 8,000 \mathrm{IU}$; vitamin $\mathrm{D}_{3}, 3,000 \mathrm{IU}$; vitamin $\mathrm{E}$, $40 \mathrm{IU}$; vitamin $\mathrm{K}_{3}, 2 \mathrm{mg}$; vitamin $\mathrm{B}_{1}, 1 \mathrm{mg}$; vitamin $\mathrm{B}_{2}, 4 \mathrm{mg}$; vitamin $\mathrm{B}_{6}, 1.5 \mathrm{mg}$; vitamin $\mathrm{B}_{12}, 0.01 \mathrm{mg}$; Ca-pantothenate, $8 \mathrm{mg}$; niacin, $25 \mathrm{mg}$; folic acid, $0.5 \mathrm{mg}$; choline chloride, $250 \mathrm{mg}$; manganese, $90 \mathrm{mg}$; zinc, $90 \mathrm{mg}$; iron, $50 \mathrm{mg}$; copper, $12 \mathrm{mg}$; iodine, $1.2 \mathrm{mg}$; selenium, $0.2 \mathrm{mg}$.

\section{Statistical analyses}

Data were subjected to two-way analysis of variance. Statistical significance was considered at $\mathrm{P}<0.05$. Statistical analyses were performed using Statgraphics software.

\section{Results}

Distillers dried grains with solubles partly replaced soybean meal and wheat in the experimental diet, and the control and experimental diets did not differ considerably in chemical composition (Table 1).

Statistically significant differences were found between the hen breeds and between the groups fed control and DDGS diets for all productive traits except the number of dead birds and egg weight (Table 2). Feeding laying hens with the DDGS diet reduced their body weight, increased egg production and improved feed conversion per egg laid. Compared to R-11 hens, Z-11 hens were characterized by lower body weight, lower egg production and poorer feed conversion $(\mathrm{P} \leq 0.01$ or $\mathrm{P} \leq 0.05)$. In all groups of layers, mortality was low and did not exceed $1.27 \%$. 


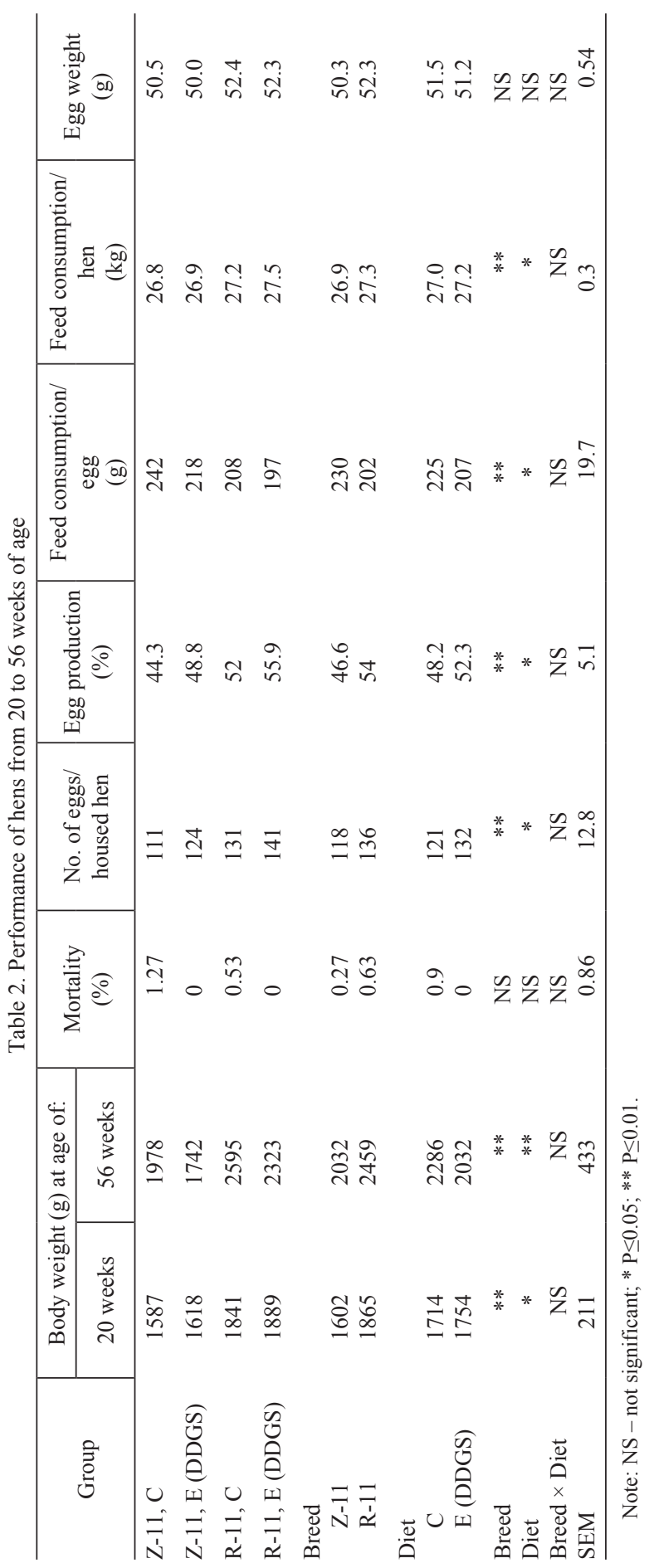




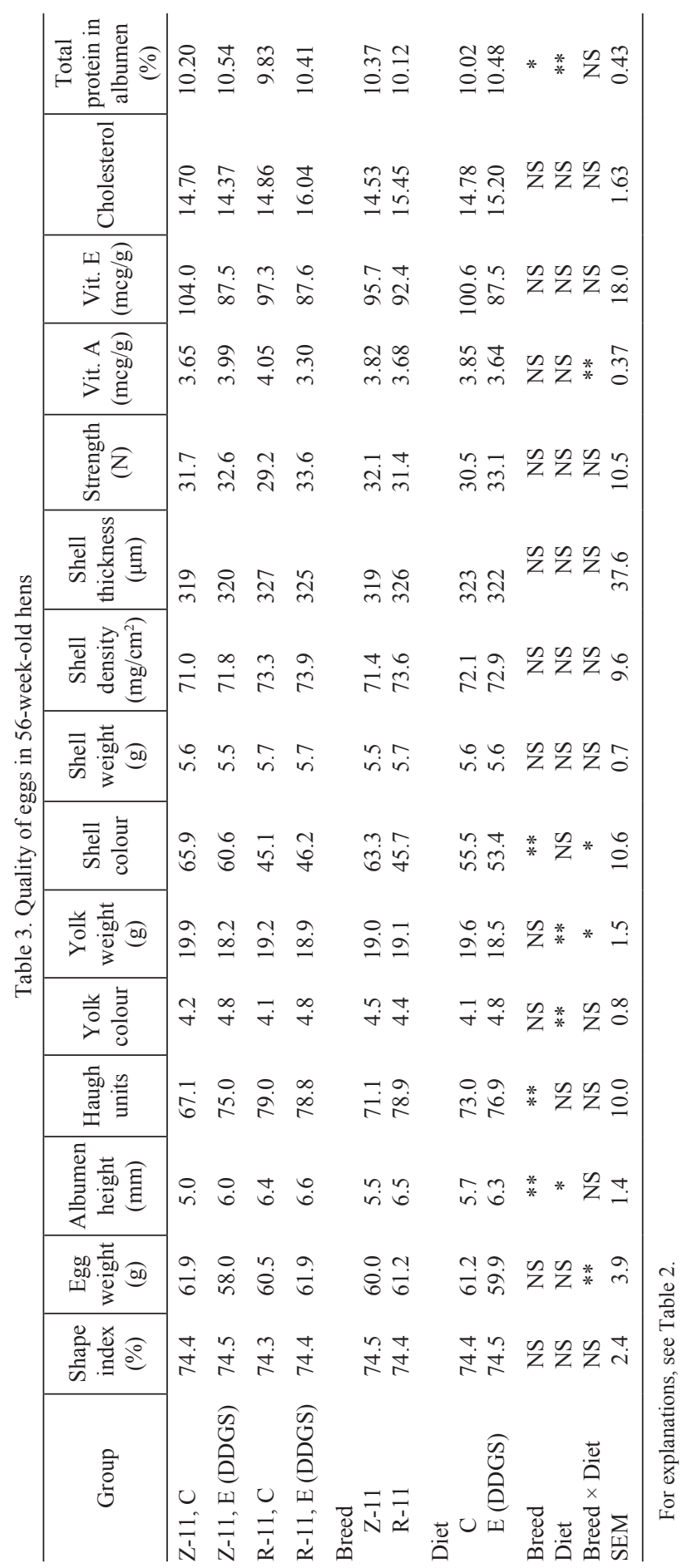




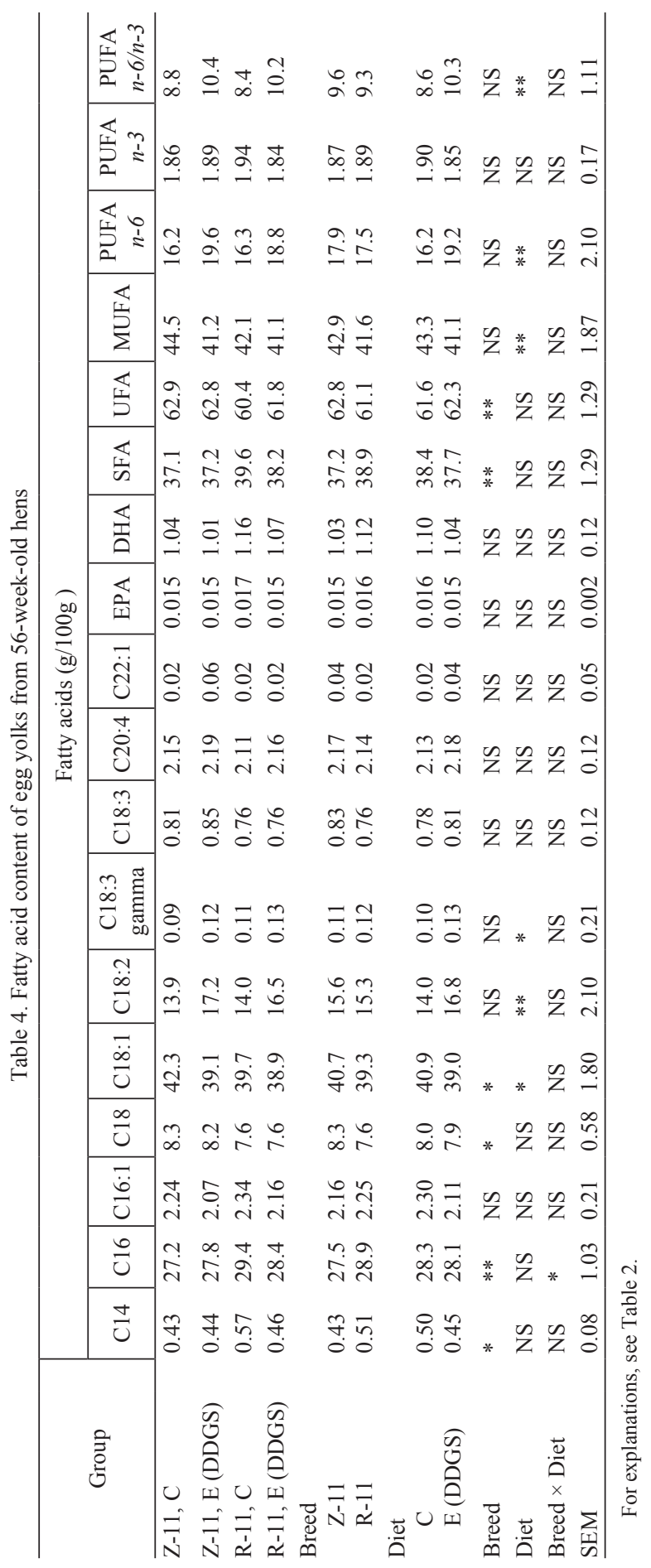


In eggs from 56-week-old hens (Table 3), greater differences in quality traits were found between the breeds than between the experimental and control groups. Eggs from hens fed the DDGS diet for 36 weeks were characterized by significantly lower weight, higher total protein content of egg albumen, and more intense yolk colour $(\mathrm{P} \leq 0.01$ or $\mathrm{P} \leq 0.05)$. Decreased yolk weight and lower vitamin $\mathrm{A}$ and $\mathrm{E}$ content were also found in hens fed the DDGS diet, but the differences were not significant. Hen's genotype and the diet used had no effect on egg shell quality.

Dietary level of $10 \%$ DDGS had an effect on the fatty acid profile of yolk lipids (Table 4). Compared to control layers, hens from experimental groups laid eggs with a numerically lower proportion of saturated fatty acids (SFA) and a greater proportion of unsaturated fatty acids (UFA), but the differences were not significant. The increases in the content of saturated fatty acids oleic (18:1) and linoleic (18:2 and 18:3), and $n-6$ PUFA were statistically significant $(\mathrm{P} \leq 0.01$ or $\mathrm{P} \leq 0.05)$. There were also significant differences between the breeds in this respect. Compared to R-11 hens, the eggs from Z-11 layers had a lower level of saturated fatty acids (C14, C16 and C18) and a higher level of mono- and polyunsaturated fatty acids.

Table 5. Lysozyme content

\begin{tabular}{l|c|c|c|c}
\hline \multirow{2}{*}{ Group } & \multicolumn{2}{c|}{ Lysozyme content $(\%)$} & \multicolumn{2}{c}{ Lysozyme activity (U/mg) } \\
\cline { 2 - 5 } & thick albumen & thin albumen & thick albumen & thin albumen \\
\hline Z-11, C & 0.304 & 0.617 & 64929.1 & 131257 \\
Z-11, E (DDGS) & 0.306 & 0.582 & 64973.3 & 123828 \\
R-11, C & 0.291 & 0.573 & 61996.3 & 121820 \\
R-11, E (DDGS) & 0.301 & 0.514 & 64091.6 & 109622 \\
Breed & & & & \\
Z-11 & 0.305 & 0.600 & 64951.2 & 127542 \\
R-11 & 0.296 & 0.544 & 63044.0 & 115721 \\
Diet & & & & \\
C & 0.297 & 0.595 & 63462.7 & 126539 \\
E (DDGS) & 0.303 & 0.549 & 64532.4 & 116725 \\
Breed & $\mathrm{NS}$ & $* *$ & $\mathrm{NS}$ & $* *$ \\
Diet & $\mathrm{NS}$ & $* *$ & $\mathrm{NS}$ & $* *$ \\
Breed $\times$ Diet & $\mathrm{NS}$ & $\mathrm{NS}$ & $\mathrm{NS}$ & $\mathrm{NS}$ \\
SEM & 0.388 & 0.068 & 8275.11 & 14267.8 \\
\hline
\end{tabular}

For explanations, see Table 2 .

Highly significant $(\mathrm{P} \leq 0.01)$ differences were found in lysozyme content of thin albumen between hen lines and between the groups fed control and DDGS diets (Table 5). Eggs from Z-11 hens were characterized by greater lysozyme content and activity in egg albumen compared to eggs from R-11 hens. Dietary inclusion of DDGS had an effect on decreasing lysozyme content and activity in thin albumen $(\mathrm{P} \leq 0.01)$, with a slight increase in lysozyme content of thick albumen. 
The experimental DDGS diet fed to laying hens did not adversely affect egg aroma, egg flavour, and yolk colour (Table 6). There were no differences in this regard between the lines.

Table 6. Sensory evaluation of eggs from 56-week-old hens

\begin{tabular}{l|c|c|c}
\hline \multicolumn{1}{c}{ Group } & Colour & Aroma & Flavour \\
\hline Z-11, C & 4.15 & 4.32 & 4.42 \\
Z-11, E (DDGS) & 4.02 & 4.12 & 4.10 \\
R-11, C & 4.05 & 4.27 & 4.25 \\
R-11, E (DDGS) & 4.22 & 4.15 & 4.30 \\
Breed & & & \\
$\quad$ Z-11 & 4.08 & 4.22 & 4.26 \\
R-11 & 4.13 & 4.21 & 4.28 \\
Diet & & & \\
$\quad$ C & 4.10 & 4.29 & 4.33 \\
$\quad$ DDGS & 4.11 & 4.13 & 4.20 \\
Breed & NS & NS & NS \\
Diet & NS & NS & NS \\
Breed $\times$ Diet & NS & NS & NS \\
SEM & 0.74 & 0.68 & 0.65 \\
\hline
\end{tabular}

For explanations, see Table 2.

Table 7. Hatchability of hens

\begin{tabular}{|c|c|c|c|c|}
\hline Group & No. of eggs & $\begin{array}{c}\text { Egg fertility } \\
(\%)\end{array}$ & $\begin{array}{c}\text { Hatchability from } \\
\text { set eggs } \\
(\%) \\
\end{array}$ & $\begin{array}{c}\text { Hatchability from } \\
\text { fertilized eggs } \\
(\%)\end{array}$ \\
\hline Z-11, C & 1400 & 86.3 & 71.0 & 86.6 \\
\hline Z-11, E (DDGS) & 1300 & 85.6 & 72.2 & 88.7 \\
\hline $\mathrm{R}-11, \mathrm{C}$ & 1250 & 86.2 & 70.6 & 86.1 \\
\hline R-11, E (DDGS) & 1250 & 88.4 & 74.6 & 88.5 \\
\hline \multicolumn{5}{|l|}{ Breed } \\
\hline Z-11 & 2700 & 85.9 & 72.7 & 87.7 \\
\hline R-11 & 2500 & 87.3 & 73.7 & 87.3 \\
\hline \multicolumn{5}{|l|}{ Diet } \\
\hline $\mathrm{C}$ & 2650 & 86.2 & 71.9 & 86.4 \\
\hline E (DDGS) & 2550 & 87.0 & 74.5 & 88.6 \\
\hline Breed & & NS & NS & NS \\
\hline Diet & & NS & NS & NS \\
\hline Breed $\times$ Diet & & NS & NS & NS \\
\hline SEM & & 3.12 & 2.84 & 2.93 \\
\hline
\end{tabular}

For explanations, see Table 2.

Regardless of genotype and the diet used, all hens were characterized by good hatchability results (Table 7). The presence of DDGS in the diet increased fertilization rate by $2.4 \%$ and hatchability from set eggs by $4 \%$, especially in group R-11, but the differences were not significant. 


\section{Discussion}

According to the genetic resources conservation programme for laying hens (www.bioroznorodnosc.izoo.krakow) in Poland, hens from conservation flocks are not selected for improved performance traits, and selection of birds for flock rotation is random. Compared to high-producing commercial flocks, native breed hens that had been unselected for many generations are characterized by considerably lower egg production and lower egg weight (Krawczyk, 2009). The lower body weight of Z-11 hens compared to R-11 hens, just like the characteristic plumage colour, is a typical phenotypic trait of these birds. A negative effect of DDGS on body weight of layers, similar to that observed in our experiment, was reported by Lilburn and Jensen (1984), when hens were fed a diet with $20 \%$ corn fermentation solubles. The above authors attributed this influence to reduction of available Lys content in the diet with high level of corn fermentation solubles.

In our experiment, the dietary inclusion of DDGS at $10 \%$ significantly increased laying performance in the groups of low-producing hens from conservation breeds (Z-11 and R-11). Research conducted to date on the use of DDGS in diets for layers provides no data on the productive parameters of hens with such low laying performance as in our study. Corresponding results were obtained for Bovans White hens, in which the dietary inclusion of $16 \%$ DDGS compared to the control group increased total egg production during a 15-week experimental period (Loar et al., 2010). However, the results obtained for high-producing layers generally indicate that a $10-15 \%$ proportion of DDGS has no effect on egg performance and feed conversion (Lumpkins et al., 2005; Roberson et al., 2005; Roberts et al., 2007). It was demonstrated that a dietary inclusion of DDGS at up to $15 \%$ has no impact on laying performance, but when added at 20\% it adversely affects egg production and decreases egg weight (Świątkiewicz and Koreleski, 2006) and reduces the digestibility of crude fat (Świątkiewicz and Koreleski, 2007 a). Loar et al. (2010) showed that DDGS does not negatively affect production results of layers even at a level of DDGS as high as $32 \%$.

Our study confirmed the beneficial effect of DDGS on egg albumen quality in both breeds of hens. Similar to a study by Jensen et al. (1978), eggs from hens fed the DDGS diet were characterized by greater albumen height and higher value of Haugh units. The increase in yolk colour intensity, found in the present study, is consistent with earlier studies by Roberson et al. (2005), Świątkiewicz and Koreleski (2006), Loar et al. (2010), Shalash et al. (2010) and Masa'deh et al. (2011) and indicates a high availability of carotenoids found in DDGS.

The eggs from layers fed the DDGS diet had, as compared to control group, a slightly different profile of fatty acids in yolk lipids. DDGS had a positive effect on increasing the nutritionally important content of oleic (C18:1) and linoleic acids $(18: 2)$, but this was accompanied by an unfavourable increase in $n-6: n-3$ ratio (by 1.7) compared to the control groups of both breeds $(\mathrm{P} \leq 0.01)$. However, in all the groups, the $n-6: n-3$ ratio was almost half that in high-producing Lohmann Brown layers raised under intensive conditions (Oziembłowski and Kaźmierska, 2009). In our study, the fatty acid profile of egg yolks from hens fed the DGGS diet was 
more favourable compared to the results obtained by Świątkiewicz and Koreleski (2007 b), because it did not increase the content of saturated acids. In a study by Cheon et al. (2008), a 20\% DDGS supplement decreased the content of oleic acid and increased the content of linoleic acid in yolk, but had no effect on the level of unsaturated fatty acids.

Lysozyme has antibacterial and antiviral activity and is increasingly used in the pharmaceutical and cosmetic industry as a natural antibiotic. In the egg, lysozyme mainly protects the embryo, and its level depends on many environmental factors (Świerczewska et al., 2003). The results of the present study correspond to those reported by Saveur and Thapon (1983), who found some changes in lysozyme activity of egg albumen when hens were fed diets with different levels of DDGS. In the present study, in the experimental groups (fed with DDGS) of both hen breeds studied, a beneficial but small increase in the lysozyme content of thick albumen was paralleled by a significant decrease in lysozyme content and a reduction in its activity in thin albumen. At the same time, lysozyme content was higher in the eggs from Z-11 compared to R-11 hens. It ought to be emphasized that dietary inclusion of DDGS can affect the microelements content in eggs (Sauveur and Thapon, 1983), which may modify the lysozyme activity in egg albumen (Kopeć et al., 2005). The positive effect of DDGS on the microelements content in the eggs is probably related to the fact that synthesis of microbial phytase occurs in the fermentation process, during production of DDGS, and this enzyme has a beneficial effect not only on phosphorus, but also on the availability of microelements for poultry (Świątkiewicz et al., 2001).

Because yolk cholesterol is critical for embryonic development, attempts at decreasing its level were unsuccessful in many studies. Similarly, in our experiment, in both breed/lines, there was no statistically confirmed effect of dietary inclusion of DDGS on egg yolk cholesterol. A previous study by Krawczyk et al. (2005) suggests that compared to other breeds and lines of laying hens, eggs from Greenleg Partridge hens show a tendency towards lower cholesterol content, which is supported by the present study.

The dietary inclusion of $10 \%$ DDGS caused no changes in eggshell quality parameters, which is consistent with the results of previous studies conducted with high-producing lines of laying hens (Jensen et al., 1978; Lumpkins et al., 2005; Roberson et al., 2005; Świątkiewicz and Koreleski, 2006; Koreleski et al., 2011).

Neither did the DDGS diet have an unfavourable effect on the organoleptic scores of cooked eggs, which is in agreement with the earlier findings (Świątkiewicz and Koreleski, 2006; Świątkiewicz and Koreleski, 2007 b; Wall et al., 2010) and confirms that it is appropriate to use DDGS in layer nutrition. Corresponding results were obtained by Loar et al. (2010), who reported that eggs from layers receiving a DDGS diet were even preferred by consumers.

In the flocks of hens participating in the conservation programme, hatchability results are one of the most important indicators of the efficiency of breeding methods used. The high biological value of hatching eggs ensures that a large number of healthy chicks will be obtained and that the breed will survive. Shalash et al. (2010) showed no effect of a DDGS diet on hatchability results. The better hatchability 
obtained by both breeds of hens in the groups fed the DDGS diet is consistent with the results of studies with turkey breeder hens (Atkinson et al., 1955; Manley et al., 1978) and confirms the appropriateness of feeding DDGS to hens of conservation breeds.

In conclusion, the results of the current study demonstrated that maize DDGS can serve as a useful source of protein in the nutrition of hens from conservation flocks, partly replacing imported soybean meal. The use of DDGS in the diets of hens from conservation flocks improved laying performance and albumen quality, increased yolk colour intensity, and had a positive effect on hatchability results without affecting sensory parameters of cooked eggs, but had an unfavourable effect on albumen lysozyme content.

\section{References}

A $11 \mathrm{e}$ n J., King R.B.N., Holme s J.J. (1979). A diet formulated from by-products and indigenous foodstuffs for laying hens. Brit. Poultry Sci., 20: 363-370.

A t k in s on R.L., F e r g u s on T.M., Q u i s e n b e rry J.H., C o u c h J.R. (1955). Dehydrated alfalfa meal, condensed fish solubles, distillers dried solubles and dried whey as supplements to a vegetable protein turkey laying diet. Poultry Sci., 34: 730-735.

Ch e o n Y.J., L e e H.L., Sh in M.H., J a n g A., L e e S.K., L e e J.H., L e e B.D., S o n C.K. (2008). Effects of corn distiller's dried grains with solubles on production and egg quality in laying hens. Asian-Aust. J. Anim. Sci., 21: 1318 - 1323.

D a m ron B.L., E $1 \mathrm{~d}$ red A.R., H arm s R.H. (1976). An improvement in interior egg quality by the feeding of brewers dried grains. Poultry Sci., 55: 1365-1366.

Folch J., Le es M., S lo an e-Stanley G.H. (1957). A simple method for the isolation and purification of total lipids from animal tissues. J. Biol. Chem., 226: 497-509.

H a r m s R.H., M or e n o S., D a m r o n B.L. (1969). Evaluation of distillers dried grains with solubles in diets of laying hens. Poultry Sci., 48: 1652-1655.

J e n s e n L.S., C h a n g C.H., W i 1 s o n S.P. (1978). Interior egg quality: improvement by distiller feed and trace elements. Poultry Sci., 57: 648-654.

J en se n L.S., M a u ri c e V.D. (1980). Dietary chromium and interior egg quality. Poultry Sci., 59: 341-346.

Ki jowski J., Leśni e row ski G. (1999). Separation, polymer formation and antibacterial activity of lysozyme. Pol. J. Food Nut. Sci., 8/49: 3-16.

Kopeć W., S kiba T., Korzeniowska M., B obak Ł., Trziszka T. (2005). Activity of protease inhibitors and lisozyme of hen's egg white depending on feed modification and egg storage. Pol. J. Food Nutr. Sci., 14/55, SI 1: 79-83.

Koreleski J., Św ią tki e wi c z S., A r c zew s ka - W ło se k A. (2011). Rapeseed cake, glycerin and distillers dried grains with solubles used simultaneously as a source of nutrients for hens in their second laying season. Ann. Anim. Sci., 11: 125-133.

K r a w c z y k J. (2009). Effect of layer age and egg production level on changes in quality traits of eggs from hens of conservation breeds and commercial hybrids. Ann. Anim. Sci., 9: 185-193.

K r a w c z y k J., C y w a - B e n k o K., W ę ż y k S. (2005). Effect of housing system on egg yolk cholesterol levels in native breeds of hens. Proc. Intern. Conf.: First international scientific poultry days, Slovakia - Nitra, 12-14 September 2005.

Le a flet A.S., Roberts S., Bregendahl K., Xin H., Kerr B.J., Russ ell J.R. (2006). Including fiber in the diet of laying hens lowers ammonia emission. 2006 Iowa State University and USDA Poultry Science Report, pp 1-5.

L i 1 b u r n M.S., J e n s e n L.S. (1984). Evaluation of corn fermentation solubles as feed ingredient for laying hens. Poultry Sci., 63: 542-547. 
Lo a r R.E., S chilling M.W., McDaniel C.D., Coufal C.D., Rogers S.F., Karges K., Corzo A. (2010). Effect of dietary inclusion level of distillers dried grains with solubles on layer performance, egg characteristics, and consumer acceptability. J. Appl. Poultry Res., 19: 30-37.

L u m p k in s B., B a t a 1 A., D a 1 e N. (2005). Use of distillers dried grains plus solubles in laying hen diets. J. Appl. Poultry Res., 14: 25-31.

Manley J.M., Voitle R.A., Harms R.H. (1978). The influence of distillers dried grains with solubles (DDGS) in the diet of turkey breeder hens. Poultry Sci., 57: 726-728.

Ma s a' d e h M.K., Purdu m S.E., H a n ford K.J. (2011). Dried distillers grains with solubles in laying hen diets. Poultry Sci., 90: 1960-1966.

Matters on L.D., T lus tohow ic z J.J., S ing sen E.P. (1966). Corn distillers dried grains with solubles in rations for high producing hens. Poultry Sci., 45: 147-151.

Oziembłowski M., Kaźmierska M. (2009). Fatty acids and cholesterol profile in egg yolk from laying hens housed in ecological conditions. In: Food technology operations. New vistas. UP Wrocław, pp. 310-315.

R ob er s o n K.D., Ka lb fle is ch J.L., P a n W., Ch a rben a u R.A. (2005). Effect of corn distiller's dried grains with solubles at various levels on performance of laying hens and egg yolk color. Internat. J. Poultry Sci., 4: 44-51.

R oberts S.A., Xin H., Kerr B.J., Rus se 11 J.R., B regendahl K. (2007). Effects of dietary fiber and reduced crude protein on nitrogen balance and egg production in laying hens. Poultry Sci., 86: $1716-1725$.

Rong-Zhen Z., Long L., Shu-T a o L., Ru-ming C., Ping-Fan R. (1999). An improved method of cholesterol determination in egg yolk by HPLC. J. Food Bioch., 23: 351-361.

S a u v e u r B., Th a p on J.L. (1983). Effect of dietary maize solubles and minerals on albumen quality of fresh and stored brown-shelled eggs. Anim. Feed Sci. Techn., 8 (3): 177-189.

Shalash S.M.M., Abou El-Wafa S., Hassan R.A., Nehad A. Ramadan, Manal S. Mahomed, Hod a E. E 1-Gabry (2010). Evaluation of distillers dried grains with solubles as feed ingredient in laying hen diets. Internat. J. Poultry Sci., 9: 537-545.

S mulikows k a S., Rutkows ki A. (2005). (Editors). (2005). Poultry Feeding Standards (in Polish). Publisher: IFiŻZ PAN Jabłonna and Polish Branch WPSA.

Św i ą tki ewicz S., Koreleski J. (2006). Effect of maize distillers dried grains with solubles and dietary enzyme supplementation on the performance of laying hens. J. Anim. Feed Sci., 15: 253-260.

Ś w i ą t k i e w i c z S., K o r e le s k i J. (2007 a). Effect of dietary level of maize- and rye distiller dried grains with solubles on nutrient utilization and digesta viscosity in laying hens. J. Anim. Feed Sci., 15: $253-260$.

Ś w i ą t k i e w i c z S., K or e le s k i J. (2007 b). Distillers dried grains with solubles from fuel ethanol production in poultry nutrition (in Polish). Rocz. Nauk. Zoot. Monogr. Rozpr., 33 ss.

Ś w i ą t k i e w i c z S., K o r e les k i J. (2008). The use of distillers dried grains with solubles (DDGS) in poultry nutrition. World's Poultry Sci. J., 64: 257-265.

Św i ątki ew ic z S., Koreleski J., Z hong D.Q. (2001). The bioavailability of zinc from inorganic and organic sources in broiler chickens as affected by addition of phytase. J. Anim. Feed Sci., 10: $317-328$.

Świerczewska R., Kopeć W., Noworyta-Głowacka J., Riedel J. (2003). Activity of egg albumen proteins in relation to hen housing systems (in Polish, with English summary). Med. Weter., 59: 157-160.

W a 11 H., J o n s s o n L., Johan s s on L. (2010). Effects on egg quality traits of genotype and diets with mussel meal or wheat-distillers dried grains with solubles. Poultry Sci., 89: 745-751. 
JÓZEFA KRAWCZYK, ZOFIA SOKOŁOWICZ, SYLWESTER ŚWIĄTKIEWICZ, JERZY KORELESKI, MAJA SZEFER

\section{Jakość jaj i wskaźniki produkcyjne kur ras zachowawczych żywionych mieszanką paszową zawierającą suszony wywar kukurydziany}

\section{STRESZCZENIE}

Celem podjętych badań była ocena wyników produkcyjnych oraz jakości jaj spożywczych i wylęgowych w stadach kur ras zachowawczych, żywionych mieszanką paszową zawierającą suszony wywar kukurydziany (DDGS). Badaniami objęto po 360 kur ras zielononóżka kuropatwiana (Z-11) i Rhode Island Red (R-11), objętych w Polsce programem ochrony zasobów genetycznych. Dobre wyniki produkcyjne niosek żywionych paszą z udziałem DDGS wskazują, że suszony wywar kukurydziany może stanowić przydatne źródło białka w żywieniu kur stad zachowawczych, zastępując częściowo importowaną śrutę sojową. Dodatek DDGS do mieszanki paszowej poprawił nieśność kur przy zachowaniu dobrych parametrów wylęgowości oraz jakości jaj spożywczych. Stwierdzono wpływ diety zawierającej DDGS na ważne z punktu widzenia dietetyki cechy jakości jaj, tj. zwiększenie udziału protein w białku jaja oraz zwiększenie koncentracji kwasu oleinowego i linolowego w lipidach żółtka, przy jednoczesnym wzroście stosunku PUFA $n$-6/PUFA $n$-3. Wprowadzenie DDGS do diety zwiększyło także intensywność barwy żółtka i wartość jednostek Haugha, nie wykazując równocześnie wpływu na jakość skorup. 